\title{
Assessment of Quality and Aroma Characteristics of Kefir Produced by Using Grain and Lyophilized Culture
}

\author{
İrem Şen Dağ ${ }^{1}$, Buket Aydeniz Güneșer ${ }^{2}$, Yonca Karagül Yüceer ${ }^{1, *}$ \\ ${ }^{1}$ Food Engineering Department, Faculty of Engineering, Çanakkale Onsekiz Mart University, Çanakkale \\ ${ }^{2}$ Food Engineering Department, Faculty of Engineering, Usak University, Usak
}

\section{Article History \\ Received: $\quad 31.03 .2021$ \\ Accepted: $\quad 08.07 .2021$ \\ Published: $\quad 20.09 .2021$}

Research Article

\begin{abstract}
Kefir is traditionally produced using kefir grains, while lyophilized culture is widely used in industry. Microbial fermentation of kefir has critical importance on its aromatic profile and sensory attributes as well as its physicochemical parameters. The main objective of this study was to compare the differences between some physical, chemical, microbiological, sensory attributes and volatile components in kefir fermented with kefir grains and lyophilized cultures during storage. The compositional characteristic of kefir cultured by both kefir grains and lyophilized starter were monitored during 21-day storage in this study. In contrast to dramatic decreases in titratable acidity, serum separation and Streptococcus spp. count, an increase in the amount of various aroma compounds including 2heptanone, butyric acid, hexanoic acid and octanoic acid was observed during storage of kefir samples. Incubation with lyophilized starter culture promoted kefir' sensory and rheological attributes besides of improving its diacetyl and acetic acid aroma intensities compared with that incubation with kefir grain. "Sour", "sweet", "salty" and "bite $\left(\mathrm{CO}_{2}\right)$ " were developed as taste terms, while "cooked" "creamy", "fermented", "dairy" and "yeast" were some aromatic terms for kefir samples developed by sensory evaluation. Consumer acceptance scores of the kefirs produced by using lyophilized cultures were higher than samples with grain.
\end{abstract}

Keywords - Aroma-active compound, kefir, kefir grain, lyophilized starter culture, sensory analysis

\section{Introduction}

Consuming fermented dairy products including yoghurt, cheese, sour cream, koumiss, and kefir have recently attracted attention due to their bioactive, functional and nutraceutical ingredients. Several researchers reported that nutrition benefits and health claims on the fermented dairy products such as regulating effect on the immune and nervous systems (Davras, Guzel-Seydim \& Tas, 2018; Lv \& Wang, 2009), treatment effect of inflammatory bowel disease (Sevencan et al., 2019), broad-spectrum antimicrobial, antimutagenic (Ahmed et al., 2013; Kussendrager \& Van Hooijdonk, 2007; Leite et al., 2013), antioxidant effects (Erdoğan et al., 2019; Mulder et al., 2008), hypertension and high cholesterol levels lowering effects (Ahmed et al., 2013; Nielsen et al., 2014).

Although kefir has consumed in different countries from Eastern Europe to Central Asia owing to their healing effects since ancient times, it has still increasingly gained popularity today. Kefir is defined as drinkable dairy product obtained by fermentation with starter cultures or kefir grains, which contain various lactic acid and acetic acid bacteria spp., and yeasts (Codex Stan, 2003; Magalhães et al., 2011). It was reported that kefir should have at least $2.7 \%$ protein, less than $10 \%$ fat, and at least $0.6 \%$ titratable acidity and $10^{7}$ and $10^{4} \mathrm{cfu} / \mathrm{g}$ LAB and yeast, respectively (Codex Stan, 2003).

Traditionally, kefir is produced from 0.3-2 mm cauliflower-shaped, white to yellow-white in color, small or large irregular kefir grains include polysaccharide matrix and coagulated milk proteins. Moreover, kefir grain contains a balanced proportion of bacteria (L. kefir, L. kefirogranum) and yeasts (S. kefir and C. kefir). These

\footnotetext{
1 (D) iremsen0610@gmail.com

2 (D) buket.guneser@usak.edu.tr

3 (D) yoncayuceer@comu.edu.tr

* Corresponding Author
} 
microorganisms are carried out to milk from grain during kefir fermentation. Afterwards, kefir grains were filtered and preserved for reusing for next batches (Chandan, 2013; Guzel-Seydim et al., 2021). The most significant distinction among kefir and the other dairy products is that kefir has self-carbonated, foamable structure and refreshing flavor because of $\mathrm{CO}_{2}$ produced by yeast during alcohol fermentation.

Formation of flavor compounds in dairy products is known as a complex process, which comprises chemical and biochemical transformation of milk constituent (Kranenburg et al., 2002). Metabolic activity of starter cultures is main source of these complex processes. In this context, several flavor compounds are formed by metabolism of lactic acid bacteria, which are dominant flora in dairy products. Among flavor compounds in dairy products, carbonyl compounds such as acetaldehyde (yoghurt), acetoin (creamy), butanone (fruity), diacetyl (butter) are defined as main compounds, and other ones are responsible for enhancement of flavor or has important role as a precursor for the formation of main flavor components (Cheng, 2010). Moreover, lactic acid and alcohol fermentations induce sour/acidic taste and yeast aroma in kefir (Chandan, 2013).

Kefir is a good source of B-group vitamins, nutritionally important minerals (calcium, potassium, sodium etc.), and bioactive peptides described as angiotensin converting enzyme inhibitor, antithrombotic activities and nerve-calming effects (Lv \& Wang, 2009), essential amino acids and conjugated linoleic acid (CLA) (Ebner et al., 2015; Sherkat, Shamsi, \&Arjmand, 2016). In addition, continuous consumption of kefir might also reduce higher glucose and LDL levels and induce to protection against to Helicobacter pylori (Ahmed et al., 2013).

Lyophilized culture is widely used culture in industry. Kefir grain is commonly used in home or small-scale production. It was known that using lyophilized culture or kefir grain can lead differences in the physicochemical, microbiological, and various sensory characteristics in the product. Comparing differences between kefir samples fermented with kefir grains and lyophilized cultures in terms of some physical, chemical, microbiological, sensory attributes and volatile components during storage were aimed in the present study.

\section{Materials and Methods}

\subsection{Materials}

Two different kefir grains (G1 and G2) and lyophilized starter cultures (L1 and L2) were used in the present study. Grains were kindly provided by Danem Ltd. (G1) (Suleyman Demirel University Techno Park) and Ankara University (G2) (Department of Dairy Technology). Lyophilized kefir cultures were provided from Danem Ltd. (L1- Sevdanem) and Chr. Hansen Bio-Kefir culture (L2-eXact ${ }^{\circledR}$ KEFIR 2) (Chr. Hansen's Laboratory, Denmark).

\subsection{Kefir Production}

Ultra-high temperature (UHT) milk (SEK Dairy Company, Bursa, Turkey) was used to produce kefir samples. Kefir grains were activated into small amount of milk at $25 \mathrm{oC}$ for 18-24 $\mathrm{h}$ in the incubator (Nüve ES120, Turkey). Activated kefir grains were inoculated ( $3 \mathrm{~g}$ grain/L milk) into UHT milk and milk samples were placed in an incubator for $18-24 \mathrm{~h}$ at $25^{\circ} \mathrm{C}$. Kefir fermentation was ended about at $\mathrm{pH} 4.8$ and all kefir grains were filtered through a sieve. Prepared kefir samples (G1, G2) were filtered into sterile jars under aseptic conditions. Remaining kefir grains were retained in previously boiled and cooled tap water in the fridge at $4^{\circ} \mathrm{C}$ to be used in the other production process. To obtain kefir produced by lyophilized culture, activation process was not needed since the lyophilized culture was self-activated. The same fermentation process was used to obtain kefir samples (L1, L2) using lyophilized culture (0.5 g culture/L milk). All samples coded as G1, G2, L1, L2 were stored at refrigerator for 21 days.

\subsection{Physicochemical and Microbial Analyses}

Total dry matter $(\%)$, protein $(\%)$ and titratable acidity (lactic acid\%) were measured in accordance with Bradley et al. (1992). $\mathrm{pH}$ and viscosity analyses were performed by using a pH meter (Sartorius BP-11, 
Germany) and a rotational viscometer (Brookfield viscosimeter DV II+Pro, Brookfield Engineering, USA), respectively. Total fat and ash contents were determined using NEN method 3059 (NEN, 1969) and AOAC method 945.46 (AOAC, 2000), respectively. Compositional analyses of the samples were carried out on the first day of storage. Serum separation of the samples were measured in accordance with Atamer \& Sezgin (1986). All chemicals, solvents and internal standards were purchased from Merck Co. (Darmstadt, Germany) and Aldrich Chemical Co. (St. Louis, USA). Number of Streptococcus spp., Lactobacillus spp. and yeast in the samples were determined according to Dave \& Shah (1996), IDF (1997) and Ünlütürk \& Turantaș (1996), respectively.

\subsection{Determination of Volatile Compounds}

Aroma active compounds were determined by Solid phase microextraction-Gas chromatographyolfactometry (SPME-GCO). To identify and quantify volatiles gas chromatography-mass spectrometry (GCMS) was used. The procedures mentioned in Sen and Karagül Yüceer (2019) were used for both GCO and GCMS analysis.

\subsection{Sensory Evaluation of Kefir Samples}

While, Spectrum ${ }^{T M}$ analysis used to identify the special taste and aroma attributes of the kefir samples, the consumer acceptance test was done by using hedonic scale (9-point) to determine liking of the samples (Meilgaard, Civille \& Carr, 1999). Five female and one male panelists (ages 24-45 years) used Spectrum ${ }^{T M}$ method to evaluate the samples. All panelists received approximately 100 hours of training to generate and define sensory descriptors. 15-point scale was used to determine the intensity of the attributes.

Consumer acceptance test of kefir samples $(25-30 \mathrm{~mL})$ were performed by using 9-point hedonic scale for appearance, consistency, and taste/flavor properties at room temperature $\left(25^{\circ} \mathrm{C}\right)$. All panelists were also asked to rank the kefir samples they liked (from most preferred with number 1 to least preferred with number 4) at the end of sensory evaluation. Consumer panel consisted of 101 subjects (mainly academician and student) evaluated the kefir samples (Meilgaard et al., 1999). All samples were served to panelists in disposable clear cups and water was provided to clean the palate.

\subsection{Statistical Analysis}

To determine the differences among the samples in terms of chemical parameters, One way-ANOVA was used. Two way-ANOVA was applied to show the effects of storage and types of culture on samples with respect to physicochemical, microbiological, and sensory characteristics. The findings of consumer analysis were evaluated by Kruskal-Wallis test (Sheskin, 2000). SPSS (1994) and Minitab (2010) were used for all statistical analysis. All analyses were duplicated.

\section{Results and Discussion}

\subsection{Physicochemical Characteristics of Kefir Samples}

Basic composition of UHT milks used to produce kefir samples were followed as $11.35-11.41 \%$ dry matter, $0.68 \%$ ash, $6.68-6.75 \mathrm{pH}, 0.18 \%$ titratable acidity, 3.26-3.47\% protein and 3-3.08\% fat contents. In this study, the basic contents of kefir samples fermented with kefir grain and lyophilized cultures were determined on the 1 st day of storage (Table 1 ). Amount of protein in the samples were ranged from 3.64 to $4.22 \%$. No significant differences among the samples in terms of protein content were detected $(P>0.05)$. 
Table 1

Basic composition of kefir samples on the first day of storage

\begin{tabular}{lllll}
\hline \multirow{2}{*}{ Content $(\%)$} & \multicolumn{4}{c}{ Kefir samples (Mean \pm SE) } \\
\cline { 2 - 5 } & G1 & G2 & L1 & L2 \\
\hline Protein & $3.64 \pm 0.17$ & $3.71 \pm 0.01$ & $3.69 \pm 0.12$ & $4.22 \pm 0.20$ \\
Fat & $2.76 \pm 0.05^{\mathrm{ab}}$ & $2.88 \pm 0.03^{\mathrm{a}}$ & $2.69 \pm 0.01^{\mathrm{b}}$ & $2.68 \pm 0.01^{\mathrm{b}}$ \\
Dry matter & $10.62 \pm 0.05^{\mathrm{b}}$ & $10.54 \pm 0.09^{\mathrm{b}}$ & $10.93 \pm 0.02^{\mathrm{a}}$ & $10.68 \pm 0.02^{\mathrm{ab}}$ \\
Ash & $0.69 \pm 0.01^{\mathrm{b}}$ & $0.68 \pm 0.01^{\mathrm{c}}$ & $0.71 \pm 0.01^{\mathrm{a}}$ & $0.69 \pm 0.01^{\mathrm{b}}$ \\
\hline a,b,c Means followed by different letters in the same row represent significant differences $(P \leq 0.05)$. SE: Stand- \\
ard error. G1 and G2: kefir samples produced by kefir grains, L1 and L2: kefir samples produced by lyophi- \\
lized starter cultures
\end{tabular}

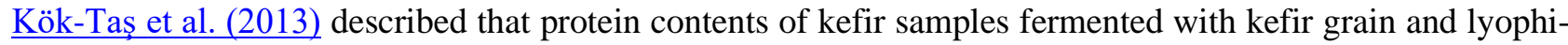
lized cultures were $3.47 \%$ and 3.45\%, respectively. Similar findings were also reported by Karagözlü (1990). Moreover, there were no significant differences in fat and dry matter contents of both kefir groups (G1-G2 and L1-L2). The fat contents of kefir samples were ranged between $2.68-2.88 \%$ whereas dry matter ranged between $10.54-10.93 \%$ in kefir samples. The findings of the present study supported by the findings of previous studies on kefir (Güzel-Seydim et al. 2005; Karagözlü 1990; Kök-Taș et al. 2013)

$\mathrm{pH}$, titratable acidity $(\%)$, serum separation $(\mathrm{mL})$ and viscosity $(\mathrm{cP})$ measurements of kefir samples fermented with kefir grain and lyophilized cultures were carried out during the storage (Table 2). The effect of storage on $\mathrm{pH}$ values in kefir samples was not significant $(P \geq 0.05)$ while kefir type affected $\mathrm{pH}$ values $(P \leq 0.05)$. Sample G2 had the highest $\mathrm{pH}$ value (4.73), while the lowest $\mathrm{pH}$ (4.35) was determined in sample L2 (Table 2). 
Table 2

The changes of physicochemical properties in kefir samples during storage

\begin{tabular}{|c|c|c|c|c|c|}
\hline \multirow{3}{*}{ Storage (days) } & \multicolumn{5}{|c|}{ Kefir samples (Mean \pm SE) } \\
\hline & G1 & G2 & L1 & L2 & Mean \\
\hline & \multicolumn{5}{|c|}{$\mathrm{pH}$} \\
\hline 1 & $4.39 \pm 0.02$ & $4.70 \pm 0.01$ & $4.39 \pm 0.01$ & $4.33 \pm 0.01$ & $4.45 \pm 0.17$ \\
\hline 7 & $4.43 \pm 0.01$ & $4.77 \pm 0.01$ & $4.43 \pm 0.02$ & $4.35 \pm 0.01$ & $4.50 \pm 0.19$ \\
\hline 21 & $4.45 \pm 0.02$ & $4.72 \pm 0.03$ & $4.45 \pm 0.03$ & $4.36 \pm 0.01$ & $4.50 \pm 0.17$ \\
\hline \multirow[t]{3}{*}{ Mean } & $4.42 \pm 0.03^{\mathrm{b}}$ & $4.73 \pm 0.04^{\mathrm{a}}$ & $4.42 \pm 0.03^{\mathrm{b}}$ & $4.35 \pm 0.02^{\mathrm{c}}$ & \\
\hline & \multicolumn{5}{|c|}{ Titratable acidity (lactic acid \%) } \\
\hline & G1 & $\mathrm{G} 2$ & L1 & L2 & Mean \\
\hline 1 & $0.82 \pm 0.01$ & $0.69 \pm 0.01$ & $0.82 \pm 0.01$ & $0.86 \pm 0.01$ & $0.80 \pm 0.07^{\mathrm{A}}$ \\
\hline 7 & $0.76 \pm 0.01$ & $0.65 \pm 0.02$ & $0.76 \pm 0.01$ & $0.78 \pm 0.01$ & $0.74 \pm 0.06^{\mathrm{B}}$ \\
\hline 21 & $0.71 \pm 0.05$ & $0.68 \pm 0.02$ & $0.74 \pm 0.02$ & $0.81 \pm 0.01$ & $0.71 \pm 0.06^{\mathrm{B}}$ \\
\hline \multirow[t]{3}{*}{ Mean } & $0.76 \pm 0.06^{\mathrm{a}}$ & $0.67 \pm 0.02^{\mathrm{b}}$ & $0.77 \pm 0.04^{\mathrm{a}}$ & $0.82 \pm 0.04^{\mathrm{a}}$ & \\
\hline & \multicolumn{5}{|c|}{ Serum separation $(\mathrm{mL})$} \\
\hline & G1 & G2 & L1 & $\mathrm{L} 2$ & Mean \\
\hline 1 & $8.25 \pm 0.25$ & $8.75 \pm 0.25$ & $8.75 \pm 0.25$ & $9.25 \pm 0.25$ & $8.75 \pm 0.41$ \\
\hline 7 & $7.60 \pm 0.25$ & $7.75 \pm 0.25$ & $8.50 \pm 0.50$ & $8.25 \pm 0.25$ & $8.03 \pm 0.42$ \\
\hline 21 & $7.75 \pm 1.25$ & $8.25 \pm 0.75$ & $8.13 \pm 0.13$ & $8.38 \pm 0.13$ & $8.13 \pm 0.27$ \\
\hline \multirow[t]{3}{*}{ Mean } & $7.87 \pm 0.34$ & $8.25 \pm 0.50$ & $8.46 \pm 0.31$ & $8.63 \pm 0.54$ & \\
\hline & \multicolumn{5}{|c|}{ Viscosity (cP) } \\
\hline & G1 & G2 & L1 & L2 & Mean \\
\hline 1 & $140.05 \pm 1.70$ & $75.80 \pm 10.20$ & $147.90 \pm 1.00$ & $148.18 \pm 1.42$ & $127.98 \pm 34.99$ \\
\hline 7 & $140.85 \pm 1.88$ & $74.60 \pm 13.30$ & $148.82 \pm 0.03$ & $149.45 \pm 0.20$ & $128.43 \pm 36.10$ \\
\hline 21 & $137.98 \pm 9.68$ & $77.90 \pm 15.50$ & $140.45 \pm 1.05$ & $141.97 \pm 0.78$ & $124.58 \pm 31.16$ \\
\hline Mean & $139.63 \pm 1.48^{\mathrm{a}}$ & $76.10 \pm 1.67^{b}$ & $146.53 \pm 4.59^{\mathrm{a}}$ & $146.53 \pm 4.00^{\mathrm{a}}$ & \\
\hline
\end{tabular}

Kök-Taș et al. (2013) evaluated pH values in the stored kefir samples fermented with kefir grains and lyophilized cultures for 21 days. The researchers reported that $\mathrm{pH}$ values of kefir samples fermented with lyophilized cultures at 1,7 and 21 days of storage were $4.49,4.39$ and 4.35 , respectively while kefir samples fermented with kefir grain had $\mathrm{pH} 4.47,4.38$ and 4.29 in 1, 7 and 21 days of storage, respectively. Differences in $\mathrm{pH}$ values of the kefir samples can be ascribed to the diversity of kefir microbial flora.

Titratable acidities $(\%)$ of the samples were expressed as lactic acid. Effects of storage and kefir varieties on the titratable acidities were statistically significant, but the interactions in storage time and kefir varieties were not found to be significant. All titratable acidities decreased during the storage period. L2 group kefirs had the highest titratable acidity $(0.82 \%)$, but kefirs in group G2 had the lowest titratable acidity $(0.67 \%)$. No distinct differences were found in titratable acidities among other kefir samples. It was thought that using different cultures in kefir production and variation in lactic acid contents of each sample had led to difference between kefir samples. Kök-Taș et al. (2013) found lactic acid contents in the kefir samples fermented with kefir grains and lyophilized cultures between $0.84-0.92 \%$ and $0.81-0.92 \%$ respectively during 21 -day storage.

Amount of serum separation $(\mathrm{mL})$ in all samples were ranged between 7.87 to $8.63 \mathrm{~mL}$ during storage period (Table 2). Effects of storage and types of culture and interactions in storage time and kefir varieties on serum separation were not found to be significant. Ersoy \& Uysal (2003) studied serum separation in kefir samples produced by kefir grain and lyophilized cultures. The results obtained for serum separation were determined 6 $\mathrm{mL}, 12 \mathrm{~mL}$ and $12 \mathrm{~mL}$ at 1,6 and 9 days of storage, respectively. The results of serum separations in G1 and $\mathrm{G} 2$ samples were higher than those reported in the literature, $\mathrm{pH}$ values of $\mathrm{G} 2$ group were lower than those reported values to first day of storage.

There was a significant difference between kefir types in terms of viscosities $(P \leq 0.05)$, while kefir type by storage interactions and storage $(P>0.05)$ were not significant in terms of viscosity values. The highest 
viscosity was determined in L1 and L2 samples $(146.53 \mathrm{cP}$ ), and the lowest mean was in G2 sample (76.10 $\mathrm{cP})$. There were no significant differences among G1, L1 and L2 samples in terms of viscosity measurements. In a study conducted by Kök-Taș et al. (2013), viscosities of samples with kefir grain were measured 225, 202 and $247 \mathrm{mPa}$.s, when the viscosities of kefir samples fermented by lyophilized cultures were recorded as 312.7, 294.3 and $292.5 \mathrm{mPa} . \mathrm{s}$ after 1,7 and 21 day, respectively.

\subsection{Microbiological Characteristics of Kefir Samples}

Changes in the counts of Streptococcus spp., and Lactobacillus spp. were presented in Table $\underline{3}$. Interaction of storage and samples on the counts of Streptococcus spp. and Lactobacillus spp was significant. Statistically significant reduction was determined in the count of Streptococcus spp. in sample L2 unlike other kefir samples during 21 day of storage $(P \leq 0.05)$. The mean counts of Streptococcus spp. in G1, G2 and L1 samples were 8.70, 8.52 and $8.62 \log \mathrm{cfu} / \mathrm{mL}$, respectively. For Lactobacillus spp., G1 sample had the lower counts than other kefir samples in the $1^{\text {st }}$ day of storage while no significant differences were observed between kefir samples on the $21^{\text {th }}$ day $(P \geq 0.05)$.

Similar results were also observed in previous studies. Kök-Taș et al. (2013) showed that Lactobacillus spp. count was ranged 8.03-9.21 log cfu/mL in kefir produced by grains while kefir samples produced from lyophilized culture had approximately $9.12 \mathrm{log} \mathrm{cfu} / \mathrm{mL}$ of Lactobacillus spp. during the 21-day storage. Yeast count in kefir samples ranged between 1.33-5.56 log cfu/L and yeast count of kefir samples had been changed depending on the type of kefir culture $(P \leq 0.05)$. Generally, kefir samples produced by lyophilized culture had the lower yeast count than kefir samples produced by kefir grains. For example, the highest yeast count was observed in G2 sample (5.56 log cfu/L), whereas L2 sample (1.33 log cfu/L) had the lowest yeast count during the storage. The result was supported by the findings of Güzel-Seydim et al. (2005). The researchers found that the count of yeast in kefir samples produced by kefir grain and lyophilized culture ranged between 5.50$5.32 \log \mathrm{cfu} / \mathrm{mL}$ and 4.77-5.0 $\log \mathrm{cfu} / \mathrm{mL}$, respectively. Moreover, the yeast count in kefir samples produced by starter kefir culture increased during storage and this increase in yeast count was not determined by the researchers for kefir samples produced by using kefir grains.

In contrast to our findings, Y1ldiz (2009) determined higher Lactobacillus spp. and yeast counts as av. 7.41 $\log \mathrm{cfu} / \mathrm{mL}$ and $8.06 \log \mathrm{cfu} / \mathrm{mL}$, respectively in kefir samples with $3 \%$ fat content during 23 -day storage at 4 ${ }^{\circ} \mathrm{C}$.

Table 3

Counts of Streptococcus spp. and Lactobacillus spp. in kefir samples during storage (log cfu/mL)

\begin{tabular}{llllll}
\hline \multicolumn{5}{c}{ Kefir samples (Mean \pm SE) } \\
\hline \multirow{2}{*}{ Storage (days) } & \multicolumn{5}{c}{ Streptococcus spp. } \\
\cline { 2 - 6 } & G1 & G2 & L1 & L2 & Mean \\
\hline 1 & $8.99 \pm 0.01^{\mathrm{Aa}}$ & $8.84 \pm 0.01^{\mathrm{Aa}}$ & $8.62 \pm 0.03^{\mathrm{Aa}}$ & $6.81 \pm 0.07^{\mathrm{Ba}}$ & $8.32 \pm 0.15$ \\
21 & $8.40 \pm 0.03^{\mathrm{Aa}}$ & $8.19 \pm 0.49^{\mathrm{Aa}}$ & $8.61 \pm 0.09^{\mathrm{Aa}}$ & $1.62 \pm 0.31^{\mathrm{Bb}}$ & $6.71 \pm 3.39$ \\
Mean & $8.70 \pm 0.42$ & $8.52 \pm 0.46$ & $8.62 \pm 0.01$ & $4.22 \pm 5.08$ & \\
\hline \multicolumn{5}{c}{ Lactobacillus spp. } \\
\cline { 2 - 6 } & $\mathrm{G} 1$ & $\mathrm{G} 2$ & $\mathrm{~L} 1$ & $\mathrm{~L} 2$ & Mean \\
\hline 1 & $4.54 \pm 0.34^{\mathrm{Bb}}$ & $6.98 \pm 0.91^{\mathrm{Aa}}$ & $8.42 \pm 0.04^{\mathrm{Aa}}$ & $7.04 \pm 0.24^{\mathrm{Aa}}$ & $6.75 \pm 1.61$ \\
21 & $6.96 \pm 0.02^{\mathrm{Aa}}$ & $6.98 \pm 0.13^{\mathrm{Aa}}$ & $7.08 \pm 0.01^{\mathrm{Ab}}$ & $6.85 \pm 0.08^{\mathrm{Aa}}$ & $6.97 \pm 0.06$ \\
Mean & $5.75 \pm 1.71$ & $6.98 \pm 0.01$ & $7.75 \pm 0.95$ & $6.95 \pm 0.06$ & \\
\hline
\end{tabular}

${ }_{\mathrm{A}, \mathrm{B}}$ Means followed by different letters represent significant differences between the means of kefir samples for the same storage day

a, b Means followed by different letters represent significant differences between the means of storage day for the same kefir sample $(P \leq 0.05)$. SE: Standard error. G1 and G2: kefir samples produced by kefir grains, L1 and L2: kefir samples produced by lyophilized starter cultures 


\subsection{Volatile Compounds of Kefir Samples}

Thirteen aroma- active compounds were detected in kefir samples in the present study. Ketones, sulfur, esters and acids are major aroma active compounds in kefir samples and their intensities varied depend on kefir samples (Table $\underline{4}$ ).

Formation of diacetyl in dairy products is mainly due to lactose and citrate metabolism of Lactococcus lactis ssp. lactis biovar. Diacetylactis and Leuconostoc spp. (Güneșer \& Karagül-Yüceer, 2011). Diacetyl was determined at higher intensity than other flavor compounds except butyric acid in all kefir samples. In general, the intensity of diacetyl of kefir samples produced from lyophilized culture was higher than those produced from kefir grain. 1-octen-3-ol is formed by lipid oxidation of milk fat and associated with mushroom or metallic flavor (Karagül-Yüceer et al., 2009). 1-octen-3-ol was determined at low intensities in all kefir samples except L1. Sample G1 had higher intensity of this flavor than others. Dimethyl sulfur and methional were associated cooked and boiled potato flavors, respectively. Both components were known as Strecker degradation products and are considered as off-flavor for dairy products (Karagül-Yüceer et al., 2009). Dimethyl sulfur was determined only in sample G1, while methional was determined in all kefir samples. In terms of methional intensity, kefir samples produced from kefir grains had higher values than those produced from starter culture.

Ester type flavor compounds are formed through the reaction of acids with alcohols. This reaction has important role in the metabolism of yeast to produce fruity flavors in the fermentation stages. Ethyl-3-methyl butyrate, which is associated fermented creamy and fruity flavors, was identified only in kefir samples produced by using kefir grains with similar intensities. This observation could be related to the count of yeast in kefir grains due to natural kefir grains contains higher yeast count than that of freeze-dried kefir cultures.

Acidic compounds determined in all kefir samples were acetic acid (vinegar), butyric acid (rancid) and hexanoic acid (cheesy). All of these compounds were associated with sharp flavor and bacterial group contained in dairy products and caused acidity came from fatty acid. Several dairy products like cheese, cream, milk powder had these acidic flavor compounds. It is considered that butyric acid is major volatile acidic compound and responsible for rancid and sour flavor of fermented dairy products (Güneșer \& Karagül-Yüceer, 2010; KaragülYüceer, Drake, \& Cadwallader, 2001;). Butyric acid and acetic acid were found in both kefir groups. Aroma intensities of acetic acid were lower in kefir samples produced by kefir grains than others. However butyric acid intensities of the kefir samples were similar. Other compounds including maltol and homofuraneol which were associated burnt sugar or caramel like flavor, were only determined L1 and L2 samples, respectively. They can be formed from lactose in dairy products by heat treatment (Cadwallader \& Singh, 2009). 
Table 4

Aroma-active compounds determined in kefir samples at the first day of storage

\begin{tabular}{|c|c|c|c|c|c|c|c|}
\hline \multirow{2}{*}{ No } & \multirow{2}{*}{ Compound } & \multirow{2}{*}{$\mathrm{RI}^{\mathrm{a}}$} & \multirow{2}{*}{ Aroma } & \multicolumn{4}{|c|}{ Aroma intensity $^{\mathrm{b}}$ (Mean \pm SE) } \\
\hline & & & & G1 & G2 & L1 & $\mathrm{L} 2$ \\
\hline 1 & Dimethyl sulphur & $<500$ & Sulphur, cooked potato & $1.00 \pm 0.01$ & ND & ND & ND \\
\hline 2 & Diacetyl & 571 & Buttery & $5.00 \pm 0.71$ & $4.50 \pm 0.71$ & $6.00 \pm 0.71$ & $5.50 \pm 0.71$ \\
\hline 3 & Acetic acid & 618 & Vinegar, sour & $1.50 \pm 0.01$ & $1.00 \pm 0.01$ & $3.00 \pm 0.01$ & $2.00 \pm 0.01$ \\
\hline 4 & Unknown 1 & 796 & Dust/concrete & ND & ND & $1.50 \pm 0.71$ & ND \\
\hline 5 & Butyric acid & 806 & Rancid & $5.50 \pm 0.71$ & $5.50 \pm 1.14$ & $6.25 \pm 0.35$ & $5.00 \pm 0.01$ \\
\hline 6 & $\begin{array}{l}\text { Ethyl-3-methyl bu- } \\
\text { tyrate }\end{array}$ & 860 & Fruity, creamy & $2.00 \pm 1.41$ & $2.00 \pm 0.35$ & $\mathrm{ND}$ & ND \\
\hline 7 & Unknown 2 & 861 & Burnt sugar & ND & ND & $1.50 \pm 0.71$ & ND \\
\hline 8 & Methional & 912 & Boiled potato & $7.25 \pm 0.35$ & $4.00 \pm 1.41$ & $3.00 \pm 1.41$ & $6.00 \pm 0.71$ \\
\hline 9 & Unknown 3 & 937 & Rose & $0.40 \pm 0.57$ & ND & $\mathrm{ND}$ & - \\
\hline 10 & 1-octen 3-ol & 986 & Mushroom & $1.50 \pm 0.01$ & $0.90 \pm 0.14$ & ND & $0.70 \pm 0.21$ \\
\hline 11 & Maltol & 1030 & Burnt sugar, caramel & ND & ND & $0.80 \pm 0.01$ & ND \\
\hline 12 & Hexanoic acid & 1046 & Cheesy & $0.50 \pm 0.71$ & ND & ND & ND \\
\hline 13 & Homofuraneol & 1165 & Burnt sugar & ND & ND & ND & $1.50 \pm 0.71$ \\
\hline
\end{tabular}

ND: not detected; ${ }^{a} \mathrm{RI}$ values calculated from gas chromatography-olfactometry results on HP-5 column, ${ }^{\mathrm{b}}$ Mean aroma intensities (postpeak intensity, 10-point scale) of kefir samples given by two sniffers on DB-5 columns. SE: Standard error. G1 and G2: kefir samples produced by kefir grains, L1 and L2: kefir samples produced by lyophilized starter cultures

Total 23 volatile compounds including ketones, aldehydes, acids, alcohols, esters, and lactones were identified in kefir samples. Sixteen of these volatiles were determined in all kefir samples (Table $\underline{5}$ ).

Acetoin, 2- heptanone, 2-nonanone and 2-undekanone as ketones were determined in kefir samples. Acetoin was determined in all kefir samples through the storage. At the $1^{\text {st }}$ and $21^{\text {th }}$ days of the storage, the acetoin content of kefir samples ranged between 31.08 and $0.38 \mu \mathrm{g} / 100 \mathrm{~g}$. The highest acetoin content was determined in L2, although G2 sample had the lowest acetoin content. The amount of acetoin increased in G2 sample during storage while a decrease in acetoin content was determined in other kefir samples. Similarly, Güzel-

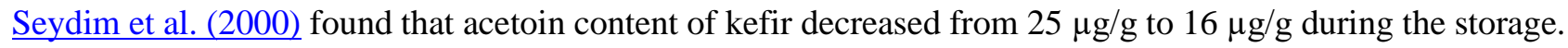
2-heptanone was determined as another ketone in all kefir samples. In general, the amount of 2-heptanone was higher in kefir samples produced from kefir grains than those of produced from starter culture. The highest amount of 2-heptanone as $2.81 \mu \mathrm{g} / 100 \mathrm{~g}$ was determined in G2 sample on the $21^{\text {st }}$ day storage and the lowest amount of 2-heptanone was determined in L2 sample on the $1^{\text {st }}$ day of the storage. G1, G2 and L1 kefir samples were similar in terms of the amount of 2-nonanone on the $1^{\text {st }}$ and $21^{\text {st }}$ day of the storage. The content of 2nonanone in kefir samples changed from $0.06 \mu \mathrm{g} / 100 \mathrm{~g}$ to $0.53 \mu \mathrm{g} / 100 \mathrm{~g}$. The amount of 2 -undecanone did not change in all kefir samples during storage.

Development of typical sour taste and acidic flavor of the kefir is the result of the acid fermentation of microbial flora in the kefir. In this study, several acidic compounds including acetic acid, butyric acid, 3-methyl butyric acid, hexanoic acid and octanoic acid were determined in kefir samples. The amount of acetic acid in kefir samples were the highest compared to other acids. Moreover, the amount of acetic acid increased during storage and kefir samples produced by using starter culture had higher acetic acid than those produced from kefir grains. 
Table 5

Volatile components ( $\mu \mathrm{g} / 100 \mathrm{~g}$ ) quantified using by solid phase microextraction (SPME)-GC-MS in kefir samples at the $1^{\text {st }}$ and $21^{\text {th }}$ days of storage

\begin{tabular}{|c|c|c|c|c|c|c|c|c|c|c|}
\hline \multirow{3}{*}{ No } & \multirow{3}{*}{ Volatile compounds } & \multirow{3}{*}{$\mathrm{RI}^{\mathrm{a}}$} & \multicolumn{8}{|c|}{ Kefir samples (Mean \pm SE) } \\
\hline & & & \multicolumn{2}{|c|}{ G1 } & \multicolumn{2}{|c|}{ G2 } & \multicolumn{2}{|c|}{ L1 } & \multicolumn{2}{|c|}{ L2 } \\
\hline & & & $1^{\text {st }}$ day & $21^{\text {th }}$ day & $1^{\text {st }}$ day & $21^{\text {th }}$ day & $1^{\text {st }}$ day & $21^{\text {th }}$ day & $1^{\text {st }}$ day & $21^{\text {th }}$ day \\
\hline 1 & Acetic acid & 598 & $137.36 \pm 1.33$ & $197.31 \pm 25.84$ & $110.18 \pm 5.27$ & $147.46 \pm 0.83$ & $153.75 \pm 33.91$ & $233.59 \pm 1.86$ & $177.19 \pm 2.13$ & $220.60 \pm 23.69$ \\
\hline 2 & Acetoin & 705 & $16.95 \pm 1.29$ & $18.03 \pm 4.41$ & $2.61 \pm 2.29$ & $0.38 \pm 0.34$ & $15.42 \pm 7.31$ & $14.70 \pm 3.38$ & $31.08 \pm 3.93$ & $25.80 \pm 10.31$ \\
\hline 3 & Isoamyl alcohol & 729 & ND & ND & ND & $5.82 \pm 0.45$ & ND & ND & ND & ND \\
\hline 4 & Butyric acid & 817 & $46.13 \pm 3.59$ & $57.12 \pm 4.42$ & $51.80 \pm 0.14$ & $52.01 \pm 14.81$ & $42.97 \pm 11.29$ & $76.67 \pm 8.77$ & $64.63 \pm 1.88$ & $65.63 \pm 6.65$ \\
\hline 5 & 3-methyl butyric acid & 856 & $1.34 \pm 0.82$ & $1.55 \pm 0.66$ & $0.77 \pm 0.12$ & $2.04 \pm 0.08$ & $0.19 \pm 0.11$ & $1.68 \pm 0.21$ & $0.80 \pm 0.57$ & $0.81 \pm 0.26$ \\
\hline 6 & Styrene & 885 & ND & ND & $0.13 \pm 0.01$ & $0.65 \pm 0.20$ & ND & ND & ND & ND \\
\hline 7 & 2-Heptanone & 890 & $1.65 \pm 0.02$ & $2.28 \pm 0.20$ & $2.50 \pm 0.12$ & $2.81 \pm 1.97$ & $1.47 \pm 0.52$ & $2.07 \pm 0.21$ & $0.44 \pm 0.18$ & $0.72 \pm 0.23$ \\
\hline 8 & 2-Heptanol & 898 & ND & ND & ND & ND & ND & ND & $0.63 \pm 0.18$ & $1.42 \pm 1.17$ \\
\hline 9 & Methoxy phenyl oxime & 909 & $1.00 \pm 0.01$ & $1.25 \pm 0.15$ & $1.43 \pm 0.03$ & $1.46 \pm 0.16$ & $0.74 \pm 0.34$ & $0.96 \pm 0.15$ & $1.08 \pm 0.03$ & $1.08 \pm 0.09$ \\
\hline 10 & Hexanoic acid & 1007 & $100.44 \pm 3.83$ & $114.71 \pm 19.82$ & $108.34 \pm 2.34$ & $110.07 \pm 30.17$ & $88.43 \pm 16.77$ & $131.04 \pm 18.42$ & $114.85 \pm 5.55$ & $127.88 \pm 16.87$ \\
\hline 11 & Heptanoic acid & 1075 & $0.83 \pm 0.59$ & $1.01 \pm 0.56$ & $0.64 \pm 0.06$ & $2.05 \pm 0.50$ & $1.57 \pm 0.57$ & $1.63 \pm 0.07$ & $0.57 \pm 0.13$ & $1.24 \pm 0.96$ \\
\hline 12 & 2-Nonanone & 1086 & $0.35 \pm 0.03$ & $0.50 \pm 0.16$ & $0.47 \pm 0.05$ & $0.53 \pm 0.26$ & $0.33 \pm 0.10$ & $0.39 \pm 0.06$ & $0.06 \pm 0.01$ & $0.06 \pm 0.01$ \\
\hline 13 & Nonanal & 1094 & ND & ND & ND & ND & ND & ND & $0.20 \pm 0.04$ & $0.30 \pm 0.16$ \\
\hline 15 & Octanoic acid & 1174 & $19.23 \pm 3.10$ & $20.68 \pm 7.65$ & $23.30 \pm 1.79$ & $21.76 \pm 5.19$ & $16.85 \pm 3.16$ & $21.11 \pm 2.01$ & $18.72 \pm 0.50$ & $27.11 \pm 5.77$ \\
\hline 16 & Nonanoic acid & 1261 & $2.84 \pm 1.37$ & $5.05 \pm 0.35$ & $0.55 \pm 0.03$ & $8.34 \pm 3.66$ & $5.06 \pm 1.64$ & $5.64 \pm 2.11$ & $0.41 \pm 0.21$ & $5.54 \pm 3.01$ \\
\hline 17 & 2-undecanone & 1284 & $0.06 \pm 0.01$ & $0.07 \pm 0.03$ & $0.09 \pm 0.01$ & $0.10 \pm 0.02$ & $0.05 \pm 0.02$ & $0.06 \pm 0.01$ & $0.05 \pm 0.01$ & $0.05 \pm 0.01$ \\
\hline 18 & Triacetin & 1339 & $0.06 \pm 0.06$ & $0.80 \pm 0.11$ & $0.03 \pm 0.03$ & $1.53 \pm 0.44$ & $0.01 \pm 0.01$ & $0.81 \pm 0.36$ & $0.01 \pm 0.01$ & $1.26 \pm 0.43$ \\
\hline 19 & n-Decanoic acid & 1356 & $5.88 \pm 4.78$ & $2.67 \pm 1.95$ & $2.35 \pm 0.09$ & $2.36 \pm 0.21$ & $1.70 \pm 0.46$ & $1.74 \pm 0.65$ & $1.52 \pm 0.01$ & $5.15 \pm 2.28$ \\
\hline 20 & $\delta$-Decalactone & 1494 & $0.03 \pm 0.01$ & $0.02 \pm 0.01$ & $0.03 \pm 0.01$ & $0.03 \pm 0.01$ & $0.03 \pm 0.01$ & $0.03 \pm 0.01$ & $0.04 \pm 0.01$ & $0.05 \pm 0.01$ \\
\hline 21 & Dodecanoic acid & 1549 & $0.30 \pm 0.25$ & $0.40 \pm 0.09$ & $0.03 \pm 0.02$ & $0.20 \pm 0.01$ & ND & ND & ND & $0.19 \pm 0.10$ \\
\hline 22 & Tetradecanoic acid & 1745 & ND & ND & ND & ND & ND & ND & ND & $0.12 \pm 0.12$ \\
\hline 23 & Hexadecanoic acid & 1944 & ND & ND & ND & ND & ND & ND & ND & $0.08 \pm 0.08$ \\
\hline
\end{tabular}

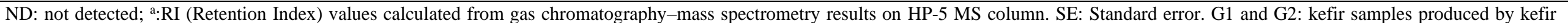
grains, L1 and L2: kefir samples produced by lyophilized starter cultures 
Butyric acid is responsible from rancid aroma in dairy products and determined in all kefir samples during storage. The highest butyric acid content was determined in sample L1 at the end of storage. Hexanoic acid is associated with cheesy and rancid flavor in food products and is responsible for pungent sour taste. The amount of hexanoic acid increased during storage in all kefir samples.

Octanoic acid is the main aroma compound in milk, and it has similar acid/sour characteristic with hexanoic acid. The amount of octanoic acid increased in G1, L1 and L2 samples during storage. However, the amount of this acid decreased in G2 sample through storage. The highest octanoic acid amount was determined in L2 samples in $21^{\text {th }}$ day of the storage.

Yeast flora in kefir has important role in alcohol fermentation. Isoamyl alcohol and 2-heptanol were only determined in G2 and L2 samples, respectively. Especially, it was thought that detection of isoamyl alcohol was associated with the highest yeast count in G2 sample on the $21^{\text {th }}$ day. The amount of 2-heptanol increased in L2 sample through 21 days of the storage.

Esters are generated by interaction of fatty acids with alcohols at mild process parameters and low cost. Aromatic esters are responsible to natural fruity and flower characteristics in foods (Sa et al., 2017). Only, triacetin, triester of acetic acid and glycerol, as ester was determined in kefir samples. The amount of triacetin increased in all kefir samples through the storage. The highest amount of triacetin was determined in G2 sample on $21^{\text {th }}$ day of the storage.

The other group of flavor compounds in dairy products is lactones. Lactones are formed by heat treatment of $\gamma$ - or $\delta$-hydroxy acids and triglycerides. Peach, sweet and milk-like flavor are associated with lactones in dairy products (Karagül-Yüceer et al., 2009). In this study, all kefir samples had $\delta$-decalactone during the storage.

\subsection{Sensorial Characteristics of Kefir Samples}

Sensory descriptors developed by the panel members for the kefir samples were shown in Table $\underline{6}$. "Sour", "sweet", "salty" and "bite" were developed taste terms for kefir samples while "cooked" "creamy", "fermented", "animal like", "dairy" and "yeast" were the aromatic terms. Similar sensory characteristic terms were determined in other dairy products (Güneșer \& Karagül-Yüceer, 2011; İșleten \& Karagül-Yüceer, 2006).

Effect of significant interaction between storage and kefir types was determined on the samples in terms of "cooked", "fermented", "dairy", "yeast", "sour", "salty" and "bite". Storage had significant effect on the creamy aroma of the kefir samples whereas animal like-aroma of the kefir samples was affected by culture type $(P<0.05)$. According to these results, cooked and dairy aroma was found to be higher in kefir samples produced from starter culture at $1^{\text {st }}$ day of the storage than those produced from kefir grain. Both aromas decreased in kefir samples produced by starter culture for 21 days storage, but the same aromas remained stable in kefir samples produced by kefir grains during storage. The highest fermented aroma was determined in L2 samples at $1^{\text {st }}$ day of the storage while there were no significant differences in other kefir samples during storage. Similarly, the highest yeast aroma was determined in G1 sample at $1^{\text {st }}$ day of the storage. At the $7^{\text {th }}$ day of storage, the lowest value was determined in G1 while the highest value was observed in G2 samples in terms of yeast aroma. Changes in yeast aroma in sample G1were significant during storage, while no significant differences were found in the other kefir samples. Moreover, the highest intensity of creamy in kefir samples was determined at the first day of the storage. After $7^{\text {th }}$ day of storage, the intensity of creamy flavor did not change in the kefir samples. Animal like aroma was found to be higher in kefir samples produced from kefir grains than kefir samples produced from lyophilized culture. 
Table 6

Sensory attributes of kefir samples during storage

\begin{tabular}{|c|c|c|c|c|c|}
\hline \multicolumn{6}{|c|}{ Kefir samples (Mean \pm SE) } \\
\hline Storage (days) & G1 & $\mathrm{G} 2$ & L1 & $\mathrm{L} 2$ & Mean \\
\hline \multicolumn{6}{|c|}{ Sour } \\
\hline 1 & $3.44 \pm 0.06^{\mathrm{Aa}}$ & $1.96 \pm 0.21^{\mathrm{Bab}}$ & $2.32 \pm 0.15^{\mathrm{Ba}}$ & $2.38 \pm 0.13^{\mathrm{Ba}}$ & $2.53 \pm 0.64$ \\
\hline 7 & $1.71 \pm 0.08^{\mathrm{Ab}}$ & $2.44 \pm 0.35^{\mathrm{Aa}}$ & $2.06 \pm 0.06^{\mathrm{Aa}}$ & $2.34 \pm 0.21^{\mathrm{Aa}}$ & $2.14 \pm 0.33$ \\
\hline 21 & $1.98 \pm 0.12^{\mathrm{Ab}}$ & $1.73 \pm 0.23^{\mathrm{Ab}}$ & $2.05 \pm 0.05^{\mathrm{Aa}}$ & $1.97 \pm 0.38^{\mathrm{Aa}}$ & $1.93 \pm 0.14$ \\
\hline Mean & $2.38 \pm 0.93$ & $2.04 \pm 0.36$ & $2.14 \pm 0.15$ & $2.23 \pm 0.23$ & \\
\hline \multicolumn{6}{|c|}{ Sweet } \\
\hline 1 & $1.86 \pm 0.11$ & $1.84 \pm 0.04$ & $2.24 \pm 0.15$ & $2.04 \pm 0.04$ & $2.00 \pm 0.19$ \\
\hline 7 & $2.11 \pm 0.19$ & $1.90 \pm 0.27$ & $2.05 \pm 0.05$ & $2.11 \pm 0.02$ & $2.05 \pm 0.10$ \\
\hline 21 & $1.99 \pm 0.11$ & $1.88 \pm 0.08$ & $1.69 \pm 0.02$ & $1.84 \pm 0.09$ & $1.85 \pm 0.12$ \\
\hline Mean & $1.99 \pm 0.13$ & $1.87 \pm 0.03$ & $1.99 \pm 0.28$ & $2.00 \pm 0.14$ & \\
\hline \multicolumn{6}{|c|}{ Salty } \\
\hline 1 & $1.21 \pm 0.04^{\mathrm{Aa}}$ & $0.71 \pm 0.05^{\mathrm{Bc}}$ & $0.75 \pm 0.01^{\mathrm{Ba}}$ & $0.65 \pm 0.15^{\mathrm{Bb}}$ & $0.83 \pm 0.26$ \\
\hline 7 & $1.12 \pm 0.11^{\mathrm{ABab}}$ & $1.25 \pm 0.01^{\mathrm{Aa}}$ & $0.93 \pm 0.03^{\mathrm{Ba}}$ & $1.00 \pm 0.01^{\mathrm{ABa}}$ & $1.08 \pm 0.14$ \\
\hline 21 & $0.93 \pm 0.02^{\mathrm{Ab}}$ & $0.98 \pm 0.01^{\mathrm{Ab}}$ & $0.94 \pm 0.06^{\mathrm{Aa}}$ & $1.01 \pm 0.11^{\mathrm{Aa}}$ & $0.97 \pm 0.04$ \\
\hline Mean & $1.09 \pm 0.14$ & $0.98 \pm 0.27$ & $0.87 \pm 0.11$ & $0.89 \pm 0.21$ & \\
\hline \multicolumn{6}{|c|}{$\mathrm{CO}_{2}$ (bite) } \\
\hline 1 & $1.71 \pm 0.04^{\mathrm{Aa}}$ & $0.44 \pm 0.02^{\mathrm{Ba}}$ & $1.69 \pm 0.12^{\mathrm{Aa}}$ & $2.01 \pm 0.09^{\mathrm{Aa}}$ & $1.46 \pm 0.70$ \\
\hline 7 & $0.36 \pm 0.03^{\mathrm{Bb}}$ & $0.36 \pm 0.06^{\mathrm{Ba}}$ & $0.60 \pm 0.03^{\mathrm{ABb}}$ & $0.91 \pm 0.03^{\mathrm{Ab}}$ & $0.56 \pm 0.26$ \\
\hline 21 & $0.59 \pm 0.05^{\mathrm{Bb}}$ & $0.60 \pm 0.18^{\mathrm{Ba}}$ & $0.97 \pm 0.03^{\mathrm{ABb}}$ & $1.06 \pm 0.27^{\mathrm{Ab}}$ & $0.81 \pm 0.25$ \\
\hline Mean & $0.89 \pm 0.72$ & $0.47 \pm 0.12$ & $1.09 \pm 0.55$ & $1.33 \pm 0.60$ & \\
\hline \multicolumn{6}{|c|}{ Cooked } \\
\hline 1 & $3.11 \pm 0.07^{\mathrm{Ba}}$ & $2.61 \pm 0.11^{\mathrm{Cb}}$ & $3.92 \pm 0.08^{\mathrm{Aa}}$ & $3.97 \pm 0.13^{\mathrm{Aa}}$ & $3.40 \pm 0.66$ \\
\hline 7 & $3.30 \pm 0.04^{\mathrm{Aa}}$ & $3.19 \pm 0.31^{\mathrm{Aa}}$ & $3.25 \pm 0.08^{\mathrm{Ab}}$ & $3.30 \pm 0.05^{\mathrm{Ab}}$ & $3.26 \pm 0.05$ \\
\hline 21 & $3.23 \pm 0.02^{\mathrm{Aa}}$ & $3.15 \pm 0.19^{\mathrm{Aa}}$ & $3.23 \pm 0.06^{\mathrm{Ab}}$ & $3.15 \pm 0.02^{\mathrm{Ab}}$ & $3.19 \pm 0.05$ \\
\hline Mean & $3.21 \pm 0.10$ & $2.98 \pm 0.32$ & $3.47 \pm 0.39$ & $3.47 \pm 0.44$ & \\
\hline \multicolumn{6}{|c|}{ Creamy } \\
\hline 1 & $4.07 \pm 0.19$ & $3.75 \pm 0.10$ & $5.46 \pm 0.25$ & $5.23 \pm 0.27$ & $4.63 \pm 0.84^{\alpha}$ \\
\hline 7 & $4.23 \pm 0.19$ & $3.65 \pm 0.52$ & $4.38 \pm 0.42$ & $4.46 \pm 0.13$ & $4.18 \pm 0.37^{\beta}$ \\
\hline 21 & $4.23 \pm 0.02$ & $3.78 \pm 0.19$ & $3.99 \pm 0.32$ & $3.94 \pm 0.27$ & $3.99 \pm 0.19^{\beta}$ \\
\hline Mean & $4.18 \pm 0.09$ & $3.73 \pm 0.07$ & $4.61 \pm 0.76$ & $4.54 \pm 0.65$ & \\
\hline \multicolumn{6}{|c|}{ Fermented } \\
\hline 1 & $5.55 \pm 0.09^{\mathrm{Aa}}$ & $3.86 \pm 0.15^{\mathrm{Bb}}$ & $5.55 \pm 0.21^{\mathrm{Aa}}$ & $5.82 \pm 0.11^{\mathrm{Aa}}$ & $5.20 \pm 0.90$ \\
\hline 7 & $5.09 \pm 0.05^{\mathrm{Aa}}$ & $5.86 \pm 0.23^{\mathrm{Aa}}$ & $5.07 \pm 0.19^{\mathrm{Aa}}$ & $5.38 \pm 0.09^{\mathrm{Aa}}$ & $5.35 \pm 0.37$ \\
\hline 21 & $5.11 \pm 0.03^{\mathrm{Aa}}$ & $4.65 \pm 0.60^{\mathrm{Ab}}$ & $5.01 \pm 0.30^{\mathrm{Aa}}$ & $5.34 \pm 0.46^{\mathrm{Aa}}$ & $5.03 \pm 0.29$ \\
\hline Mean & $5.25 \pm 0.26$ & $4.79 \pm 1.01$ & $5.21 \pm 0.30$ & $5.51 \pm 0.27$ & \\
\hline \multicolumn{6}{|c|}{ Animal-like } \\
\hline 1 & $0.71 \pm 0.17$ & $0.85 \pm 0.07$ & $0.02 \pm 0.02$ & $0.09 \pm 0.01$ & $0.42 \pm 0.42$ \\
\hline 7 & $1.61 \pm 0.06$ & $2.11 \pm 0.98$ & $0.00 \pm 0.01$ & $0.00 \pm 0.01$ & $0.93 \pm 1.09$ \\
\hline 21 & $0.33 \pm 0.01$ & $1.80 \pm 0.55$ & ND & ND & $0.53 \pm 0.86$ \\
\hline Mean & $0.88 \pm 0.66^{\mathrm{x}}$ & $1.59 \pm 0.66^{\mathrm{x}}$ & $0.01 \pm 0.01^{\mathrm{y}}$ & $0.03 \pm 0.05^{\mathrm{y}}$ & \\
\hline \multicolumn{6}{|c|}{ Dairy } \\
\hline 1 & $2.88 \pm 0.13^{\mathrm{Bb}}$ & $3.88 \pm 0.09^{\mathrm{ABa}}$ & $4.48 \pm 0.40^{\mathrm{Aa}}$ & $4.17 \pm 0.13^{\mathrm{Aa}}$ & $3.85 \pm 0.69$ \\
\hline 7 & $5.51 \pm 0.42^{\mathrm{Aa}}$ & $4.36 \pm 0.65^{\mathrm{ABa}}$ & $4.13 \pm 0.09^{\mathrm{Ba}}$ & $4.11 \pm 0.06^{\mathrm{Ba}}$ & $4.53 \pm 0.67$ \\
\hline 21 & $3.88 \pm 0.09^{\mathrm{Ab}}$ & $3.80 \pm 0.47^{\mathrm{Aa}}$ & $1.59 \pm 0.09^{\mathrm{Bb}}$ & $1.59 \pm 0.09^{\mathrm{Bb}}$ & $2.72 \pm 1.30$ \\
\hline Mean & $4.09 \pm 1.33$ & $4.01 \pm 0.30$ & $3.40 \pm 1.58$ & $3.29 \pm 1.47$ & \\
\hline \multicolumn{6}{|c|}{ Yeast } \\
\hline 1 & $4.57 \pm 0.19^{\mathrm{Aa}}$ & $2.98 \pm 0.27^{\mathrm{Ba}}$ & $2.70 \pm 0.02^{\mathrm{Ba}}$ & $3.01 \pm 0.13^{\mathrm{Ba}}$ & $3.32 \pm 0.85$ \\
\hline 7 & $1.00 \pm 0.01^{\mathrm{Bc}}$ & $2.79 \pm 1.16^{\mathrm{Aa}}$ & $1.84 \pm 0.09^{\mathrm{Aba}}$ & $1.82 \pm 0.07^{\mathrm{ABa}}$ & $1.86 \pm 0.73$ \\
\hline 21 & $2.44 \pm 0.02^{\mathrm{Ab}}$ & $2.57 \pm 0.40^{\mathrm{Aa}}$ & $2.03 \pm 0.11^{\mathrm{Aa}}$ & $2.15 \pm 0.27^{\mathrm{Aa}}$ & $2.30 \pm 0.25$ \\
\hline Mean & $2.67 \pm 1.80$ & $2.78 \pm 0.21$ & $2.19 \pm 0.45$ & $2.33 \pm 0.61$ & \\
\hline
\end{tabular}

ND: not detected; ${ }^{\mathrm{x}-\mathrm{y}}$ Means followed by different letters represent significant differences in kefir samples for animal like aroma $\left((P \leq 0.05){ }^{\alpha-\beta}\right.$ Means followed by different letters represent significant differences in kefir samples for creamy aroma $(P \leq 0.05){ }^{\mathrm{a}-\mathrm{c}}$ Means followed by different letters represent significant differences in the same kefir types during storage $(P \leq 0.05){ }^{\mathrm{A}-\mathrm{B}}$ Means followed by different letters represent significant differences among the kefir samples $(\mathrm{P} \leq 0.05)$. $\mathrm{G} 1$ and G2: kefir samples produced by kefir grains, L1 and L2: kefir samples produced by lyophilized starter cultures 
Sour, salty and bite intensities changed depending on kefir types during storage. No significant differences were found among kefir samples in terms of sweet taste. The intensity of sweet taste in kefir samples ranged between 1.69 to 2.24 scores. On the $1^{\text {st }}$ day of the storage, G2, L1 and L2 samples had similar sensory scores with regards to sour and salty taste while G1 sample had the highest score for the same taste attributes. After $1^{\text {st }}$ day of storage, perception of sour and salty tastes increased in G2, L1 and L2 samples and there were not significant differences were determined in sour and salty tastes of all kefir samples through the end of storage. $\mathrm{CO}_{2}$ can be formed by microbial metabolism in some dairy foods. The lowest bite score was determined in G2 sample at the first day of the storage and this sensory property was not change in G2 samples during storage. In case of other kefir samples, bite perception of the panelists decreased through 21 days of the storage. This could be related to the decreasing of $\mathrm{CO}_{2}$ production by microorganisms.

Consumer perception of the samples were evaluated by 9-point hedonic scale. The differences between the evaluated sensory properties were mostly due to consistency and taste/flavor attributes. Moreover, statistically significant difference $(P \leq 0.05)$ was also observed in the appearance of $\mathrm{G} 2$ sample with the lowest score (5.23). The higher sensory scores were found in samples produced with lyophilized cultures as considered from consistency and taste/flavor scores. For example, taste/flavor scores of L1 and L2 samples were between 6.66 and 6.41, while samples G1 and G2 had 6.14 and 4.49 scores, respectively.

Kefir samples belong to $G$ groups have the lowest viscosity during the storage may be associated with the lowest consistency scores in G2 samples. Similar findings to our results for kefir samples have been reported. In a study, some sensory attributes of kefir samples produced using kefir grain and lyophilized cultures were evaluated during the 9-day storage and reported that no significant difference in appearance and consistency scores was observed between tested kefir samples (Ersoy \& Uysal, 2003).

Güneșer \& Karagül-Yüceer (2010) used cow and goat milk combinations (100\% cow milk, 75\% cow milk $+25 \%$ goat milk, $50 \%$ cow milk $+50 \%$ goat milk, $100 \%$ goat milk) for the formulation of four different kefir samples. Researchers compared the appearance and consistency scores of all kefir formulations but did not find the statistically significant difference. Ersoy \& Uysal (2003) and Y1ldiz (2009) reported that the storage period had negative effect (reducing scores) on the taste-flavor attributes of kefir samples.

Consumer preference of the sample L1 by the panelists is higher than the samples L2, G1and G2. Sample G2 had the least preferred kefir. We believe the reason behind the observed the lowest overall acceptance score of G2 might be related to lower taste and aroma attributes including sour, sweet, $\mathrm{CO}_{2}$ (bite), creamy, fermented, and higher scores of animal-like and yeast aromas.

\section{Conclusion}

In this study, physicochemical, microbiological properties, and aroma compounds of kefir samples varied by using the kefir grains or lyophilized cultures. Particularly, using lyophilized culture ensured more preferred results. Intensities of diacetyl and acetic acid were higher in samples with lyophilized cultures. Consumer acceptance scores of the samples with lyophilized cultures were higher than samples with grain. Furthermore, the only fermentation with kefir grain was not efficient enough to be liked in terms of consistency, taste/flavor, and appearance of kefir samples. 


\section{Acknowledgement}

This study was funded by the Scientific Research Council of Çanakkale Onsekiz Mart University with grant number FYL:2014-339.

\section{Author Contributions}

İrem Şen Dağ: Collected data and performed the analysis in her master thesis.

Buket Aydeniz-Güneşer: Performed statistical analysis and wrote the paper.

Yonca Karagül-Yüceer: Designed the experiments, contributed to review of the manuscript and editing as a corresponding author.

\section{Conflict of Interest}

The authors declare that they have no conflicts of interest.

\section{References}

Ahmed, Z., Wang, Y., Ahmad, A., Khan, S. T., Nisa, M., Ahmad, H., \& Afreen, A. (2013). Kefir and health: A contemporary perspective. Critical Reviews in Food Science and Nutrition, 53, 422-434. https://www.tandfonline.com/doi/abs/10.1080/10408398.2010.540360

AOAC, (2000). Ash of milk (Gravimetric method)-method 945.46. In W. Horowitz (Ed.) Official methods of analysis of AOAC International (18th ed.). (pp. 19-21). Gaithersburg MD USA: AOAC International. Retrieved from: http://www.aoacofficialmethod.org/index.php?main_page=product_info\&products_id=1155

Atamer, M., \& Sezgin, E. (1986). Yoğurtlarda kurumadde artırımının pıhtının fiziksel özelliklerine etkisi. Gida, 11, 327-331. https://doi.org/6803/91480

Bradley, R. L., Arnold, Jr. E., Barbano, Jr. D. M., Semerad, R. G., Smith, D. E., \& Vines, B. K. (1992). Chemical and physical methods. In R. T. Marshall (Ed.) Standard methods for the examination of dairy products. American Public Health Association, Washington, USA. Retrieved from: http://www.sciepub.com/reference/43176

Cadwallader, K. R., \& Singh, T. K. (2009). Flavours and off-flavours in milk and dairy products. In P. L. McSweeney P. F. Fox (Eds.), Advanced Dairy Chemistry (pp 631-690). New York, USA. https://doi.org/ 10.1007/978-0-387-84865-5_14

Chandan, R. C. (2013). History and Consumption Trends. Manufacturing Yogurt and Fermented Milks. In R. T. Marshall (Ed.), Standard methods for the examination of dairy product, chemical and physical methods (pp. 433-531). Washington, USA. https://doi.org/10.1002/9781118481301

Cheng, H. (2010). Volatile flavor compounds in yogurt: a review. Critical reviews in food science and nutrition, 50(10), 938-950. https://doi.org/10.1080/10408390903044081

Codex Alimentarius Commission, (2003). Codex standard for fermented milks. Alimentarius Commission Joint FAO/WHO Food Standards Programme and World Health Organization. No. CODEX Stan 2432003. Retrieved from: http://www.fao.org/fao-who-codexalimentarius/shproxy/en/?lnk=1\&url=https\%253A\%252F\%252Fworkspace.fao.org\%252Fsites\%252Fcodex\%252FStandards\%252FCXS\%2B243-2003\%252FCXS_243e.pdf

Dave, R., \& Shah, N. (1996). Evaluation of media for selective enumeration of Streptococcus thermophilus Lactobacillus delbrueckii ssp. bulgaricus Lactobacillus acidophilus and Bifidobacteria. Journal of Dairy Science, 79, 1529-1536. https://doi.org/10.3168/jds.S0022-0302(96)76513-X

Davras, F., Guzel-Seydim, Z. B., \& Tas, T. K. (2018). Immunological effects of Kefir produced from Kefir grains versus starter cultures when fed to mice. Functional Foods in Health and Disease, 8(8), 412-423. https://www.ffhdj.com/index.php/ffhd/article/view/533/RemoteURL 
Ebner, J., Arslan, A. A., Fedorova, M., Hoffmann, R., Küçükçetin, A., \& Pischetsrieder, M. (2015). Peptide profiling of bovine kefir reveals 236 unique peptides released from caseins during its production by starter culture or kefir grains. Journal of Proteomics, 117, 41-57. https://doi.org/10.1016/j.jprot.2015.01.005

Erdogan, F. S., Ozarslan, S., Guzel-Seydim, Z. B., \& Taş, T. K. (2019). The effect of kefir produced from natural kefir grains on the intestinal microbial populations and antioxidant capacities of Balb/c mice. Food Research International, 115, 408-413. https://doi.org/10.1016/j.foodres.2018.10.080

Ersoy, M., \& Uysal, H. (2003). Süttozu, peyniraltı suyu tozu ve yayıkaltı karışımları ile üretilen kefirlerin özellikleri üzerine bir araştırma II: Bazı fiziksel ve duyusal özellikler, Ege Üniversitesi Ziraat Fakültesi Dergisi, 40(1), 79-86. http://dx.doi.org/ 1018-8851

Güneşer, O. \& Karagül-Yüceer, Y., (2010). Keçi sütünün kefir üretiminde kullanılması: Fiziksel, kimyasal ve duyusal özellikler, Ulusal Keçicilik Kongresi (pp. 336-342), Çanakkale, Turkey. Retrieved from: https://www.researchgate.net/publication/288850630_Keci_sutunun_kefir_uretiminde_kullanilmasi_Fiziksel_kimyasal_ve_duyusal_ozellikler

Güneser, O., \& Karagül-Yuceer, Y. (2011). Characterisation of aroma-active compounds, chemical and sensory properties of acid-coagulated cheese: Circassian cheese. International Journal of Dairy Technology, 64(4), 517-525. https://doi.org/10.1111/j.1471-0307.2011.00703.x

Güzel-Seydim, Z. B., Seydim, A. C., \& Greene, A. K. (2000). Organic acids and volatile flavor components evolved during refrigerated storage of kefir. Journal of Dairy Science, 83, 275-277. https://doi.org/10.3168/jds.S0022-0302(00)74874-0

Güzel-Seydim, Z. B., Wyffels, J. T., Seydim, A. C., \& Greene, A. K. (2005). Turkish kefir and kefir grains: microbial enumeration and electron microscobic observation. International Journal of Dairy Technology, 58(1), 25-29. https://doi.org/10.1111/j.1471-0307.2005.00177.x

Güzel-Seydim, Z. B., Gökırmaklı, Ç., \& Greene, A. K. (2021). A comparison of milk kefir and water kefir: Physical, chemical, microbiological and functional properties. Trends in Food Science \& Technology, 113, 42-53. https://doi.org/10.1016/j.tifs.2021.04.041

IDF, (1997). Standard I. D. F. 149A Dairy starter cultures of lactic acid bacteria (LAB). Standard of identity. Brussels, Belgium: International Dairy Federation. Retrieved from: https://www.iso.org/stand$\operatorname{ard} / 44069 . h t m l$

İşleten M, \& Karagül-Yüceer Y. (2006). Effects of dried dairy ingredients on physical and sensory properties of nonfat yogurt. Journal of Dairy Science, 89, 2865-2872. https://doi.org/10.3168/jds.S0022$\underline{0302(06) 72559-0}$

Karagözlü, C. (1990). Farklı ısll işlem uygulanmış inek sütlerinden kefir kültürü ve tanesi ile üretilen kefirlerin dayanıklılı̆̆ ve nitelikleri üzerine araştırmalar (In Turkish) (Unpublished master's thesis). Ege University, İzmir, Turkey.

Karagül-Yüceer, Y., Drake, M., \& Cadwallader, K. R. (2001). Aroma-active components of nonfat dry milk. Journal of Agricultural and Food Chemistry, 49, 2948-2953. https://doi.org/10.1021/jf0009854

Karagül-Yüceer, Y., Tuncel, B., Güneser, O., Engin, B., Isleten, M., Yasar, K., \& Mendes, M. (2009). Characterization of aroma-active compounds, sensory properties and proteolysis in Ezine cheese. Journal of Dairy Science, 92, 4146-4157. https://doi.org/10.3168/jds.2009-2124

Kök-Taş, T., Seydim, A. C., Özer, B., \& Guzel-Seydim, Z. B. (2013). Effects of different fermentation parameters on quality characteristics of kefir. Journal of Dairy Science, 96, 780-789. https://doi.org/10.3168/jds.2012-5753

Kranenburg, R., Kleerebezem, M., Vlieg, J. H., Ursing, B. M., Boekrost, J., Smit, B. A., Ayad, E. H. E., Smit, G., \& Siezen, R. (2002). Flavour formation from amino acids by lactic acid bacteria: Predictions from genome sequence analysis. International Dairy Journal, 12, 111-121. https://doi.org/10.1016/S09586946(01)00132-7 
Kussendrager, K. D., \& Van Hooijdonk, A. C. M. (2007). Lactoperoxidase: Physico-chemical properties, occurrence, mechanism of action and applications. British Journal of Nutrition, 84, 19-25. https://doi.org/10.1017/S0007114500002208

Leite, A. M. D. O., Miguel, M. A. L., Peixoto, R. S., Rosado, A. S., Silva, J. T., \& Paschoalin, V. M. F. (2013). Microbiological, technological and therapeutic properties of kefir: A natural probiotic beverage. Brazilian Journal of Microbiology, 44, 341-349. https://doi.org/10.1590/S1517-83822013000200001

Liu, J. R., \& Lin, C. W. (2000). Production of kefir from soymilk with or without added glucose, lactose, or sucrose. Journal of Food Science, 65(4), 716-719. https://doi.org/10.1111/j.1365-2621.2000.tb16078.x

Lv, J. P., \& Wang, L. M. (2009). Bioactive components in kefir and koumiss. In Bioactive components in milk and dairy products. Young W, ed. Singapore: Wiley-Blackwell. https://doi.org/10.1002 / $\underline{9780813821504}$

Magalhães, K. T., Dragone, G., De Melo Pereira, G. V., Oliveira, J. M., Domingues, L., Teixeira, J. A, Silva, J. B. A., \& Schwan, R. F. (2011). Comparative study of the biochemical changes and volatile compound formations during the production of novel whey-based kefir beverages and traditional milk kefir. Food Chemistry, 126, 249-253. https://doi.org/10.1016/j.foodchem.2010.11.012

Meilgaard, M., Civille, G. V. \& Carr, B. T. (1999). Descriptive analysis techniques, sensory evaluation Techniques ( $3^{\text {rd }}$ edn). Boca Raton, F, USA: CRC Press. https://doi.org/10030917645

Mulder, A. M., Connellan, P. A., Oliver, C. J., Morris, C. A., \& Stevenson, L. M. (2008). Bovine lactoferrin supplementation supports immune and antioxidant status in healthy human males. Nutrition Research, 28, 583-589. https://doi.org/10.1016/j.nutres.2008.05.007

NEN, (1969). Netherlands Standard 3059.Butyrometric Determination of the Fat Content of Cheese (Gerber van Gulik Method). Netherlands Milk and Dairy Journal, 23, 214-220.

Nielsen, B., Gürakan, G. C. \& Ünlü, G. (2014). Kefir: A multifaceted fermented dairy product. Probiotics and Antimicrobial Proteins, 6, 123-135. https://pubmed.ncbi.nlm.nih.gov/25261107/

Sa, A. G. A., de Meneses, A. C., de Araújo, P. H. H., \& de Oliveira, D. (2017). A review on enzymatic synthesis of aromatic esters used as flavor ingredients for food, cosmetics and pharmaceuticals industries. Trends in Food Science \& Technology, 69, 95-105. https://doi.org/10.1016/j.tifs.2017.09.004

Sevencan, N. O., Isler, M., Kapucuoglu, F. N., Senol, A., Kayhan, B., Kiztanir, S., \& Kockar, M. C. (2019). Dose-dependent effects of kefir on colitis induced by trinitrobenzene sulfonic acid in rats. Food Science, Nutrition, 7(9), 3110-3118. https://doi.org/10.1002/fsn3.1174

Sherkat, F., Shamsi, K., \& Arjmand, A. (2016). Fermented functional beverages (kefir, koumiss and ayran). In F. Shahidi, \& C. Alasalvar (Ed.) Handbook of Functional Beverages and Human Health. Boca Raton, USA. Retrieved from: https://www.routledgehandbooks.com/doi/10.1201/b19490-67

Sheskin, D. J. (2000). Parametric and nonparametric statistical procedures. New York, USA. Retrieved from: http://fmipa.umri.ac.id/wp-content/uploads/2016/03/David_J._Sheskin_David_Sheskin_Handbook_of_ParaBookFi.org_.pdf

Şen, İ. \& Karagül Yüceer, Y. (2019). Dane veya Liyofilize Kefir Kültürü Kullanılarak Peyniraltı Suyu İçeceği Üretimi ve Karakterizasyonu. Akademik Gıda, 17(3) 362-370, https://dergipark.org.tr/en/download/ar$\underline{\text { ticle-file/856668 }}$

Ünlütürk, A., \& Turantaş, F. (1996). Glda Mikrobiyolojisi Uygulamaları. İzmir: Ege Üniversitesi Basımevi. Retrieved from: https://www.nadirkitap.com/gida-mikrobiyolojisi-uygulamalari-adnan-unluturk-fulyaturantas-kitap10756882.html

Yıldız F., 2009. Farklı Yă̆ Oranlarının ve Farklı Starter Kültürlerin Kefirin Nitelikleri Üzerine Etkisi (In Turkish) (Unpublished doctoral dissertation). Ankara University, Ankara, Turkey. 